\title{
MACAU'S BRIDGING ROLE BETWEEN CHINA AND LATIN AMERICA
}

Since the beginning of the $21^{\text {st }}$ century, sustained and rapid growth in relations between China and the Latin American and Caribbean countries has been witnessed. It is widely believed that a stronger tie with a promising future can be envisaged.

Historically, Macau has been a Portuguese trading post in the Far East for over 442 years. After the Handover in 1999, Macau was officially returned to China as a Special Administrative Region. At present, Macau is the "world's top gaming capital" and a part of the Greater Bay Area of national strategic importance in southern China. By capitalizing on her core strengths and special privileges, Macau can go much further, not only as a gaming and tourism city but also an effective and efficient platform between China and Latin America.

Furthermore, with the new mega structure, the vast logistic network and the endorsed Greater Bay Area initiative, Macau can serve as an effective soft-power hub of the nation for helping build an extension of the "Belt and Road" to Latin America in the Pacific Rim.

Keywords: Macau, Special Administrative Region of China, Greater Bay Area, Belt and Road, China-Latin America Relations

\section{Introduction}

From the historical point of view, we can presume that contacts between Latin America and Asia have always existed, although mostly commercial ones, having in mind that Spanish and Portuguese empires kept expanding their colonial power and administration in the Philippines and the Pacific Rim. It is a well-known historical fact that famous Spanish navigators discovered and established the map of new commercial shipping routes between America and Far East, after year 1520 when the Strait of Magellan was discovered and the Spaniards came to the Philippines. But in general, we could underline that Spanish political and economic priority was centered in the so-called "New

Macao Association for the Promotion of Exchange Between Asia-Pacific and Latin America (MAPEAL), Macao S.A.R. China; sonia@mapeal.org 
World" and therefore they maintained eminently commercial activities in this part of the world.

Concerning China - Latin America Relations, it is necessary to underline that their origin could be traced back to the Ming Dynasty $(1368-1644)$. It all started with the Maritime Silk Road. Along with the routes, silk, porcelain, cotton yarn and other valuable commodities were shipped mostly to Mexico and Peru in the middle of the Ming Dynasty. Nevertheless, due to geographic distance and cultural differences, the earliest official ties between China and the Latin American countries could have been established only between 1870s and 1900 s with Peru, Brazil, Mexico, Cuba and Panama.

For example, with the rise of the plantations in the mid-nineteenth century and the lack of labor force, the public sector of independent Latin American countries initiated the so-called "traffic of Coolies". "Coolies" were Chinese workers who came to Cuba, the rest of the Caribbean region, Peru and later on to Chile under the eight years labor contracts. ${ }^{1}$

However, the general overview of Asian - Latin American relations could be understood as the result of negative and highly vulnerable international position of Latin American countries after the independence. Nevertheless, a few examples indicate in some cases the existence of long tradition and interests in establishing formal relations with the governments of China and Japan. In the Mexican case, it is important to stress that the first contacts with China were established during the Ming Dynasty, but both countries signed the Treaty of Friendship, Commerce and Navigation in 1888, representing the first official document for the establishment of diplomatic relations between the two countries. Concerning Chile, the historical background shows that not only trade connections were established with China and Japan, but also with India. It is well known that commercial boats from Chilean port of Valparaiso sailed to Calcutta, Hong Kong, Canton and Manila, loaded with copper and other nitrates. Following this development intensive trade exchange lasted until the mid-nineteen century. Formally, China and Chile didn't establish diplomatic relations because China refused to receive consuls from those countries that had not signed Agreement on Friendship and Trade. Finally, formal diplomatic relations between China and Chile were established in 1906.

In contrast to many western countries, China has been trying to build up a strong and lasting friendship with the Latin American countries without bundling it with politics. In 2014, the Forum of China and Community of Latin American and Caribbean States, abbreviated as Foro China-CELAC in Spanish and ChinaCELAC Forum in English, was officially established. "The China-CELAC Forum aims to promote the development of the Comprehensive Cooperative Partnership between China and Latin America and the Caribbean, characterized by equality, mutual benefit and shared development. China-CELAC Forum includes China

Carredano Juan B. Amores, Historia de América, Ariel, Barcelona, Spain, 2006, pp. 627-648. 
and the 33 member states of CELAC: Antigua and Barbuda, Argentina, Bahamas, Barbados, Belize, Bolivia, Brazil, Chile, Colombia, Costa Rica, Cuba, Dominican Republic, Dominica, Ecuador, El Salvador, Grenada, Guatemala, Guyana, Haiti, Honduras, Jamaica, Mexico, Nicaragua, Panama, Paraguay, Peru, Saint Kitts and Nevis, Santa Lucia, Saint Vincent and the Grenadines, Suriname, Trinidad and Tobago, Uruguay, and Venezuela". ${ }^{2}$

As of 2017, out of 33 Latin American countries, $22^{3}$ have already established diplomatic ties with China. Trade between China and Latin America and the Caribbean has leaped from US\$12 billion in 2000 to around US $\$ 266$ billion $^{4}$ in 2017. With closer economic cooperation and ties, China has already become the top trading partner of Brazil, Chile and Peru. Since the beginning of the $21^{\text {st }}$ century, sustained and rapid growth in relations between China and the Latin American and Caribbean countries has been witnessed. It is widely believed that a stronger tie coupled with a more promising future can be envisaged.

\section{Macau's Bridging Role between China, the Latin American and Caribbean Countries}

Macau, a special administrative region of China gifted with a unique historical background and a well-blended culture of the east and west, is fundamentally different from the other cities in the mainland. Among all the differences, the historical link of Macau with the Latin world is well considered as her unique and strategically essential quality for connecting China with Latin America. In addition, her present status of a Special Administrative Region in China is definitely an important add-on that can help enforce her bridging role between China and the Latin world in the era of globalization.

\subsection{Macau's Historical Background}

Macau (also spelled Macao), a small city located on the estuary of the Pearl River Delta in the southern part of China, has long been recognized as the gateway of China to the Latin world. "It is not an exaggeration to claim that Macao is a creation of globalization and migration. If the dawn of globalization can be traced to the accelerated flow of goods and people around the globe, spearheaded by the Portuguese explorers looking for spices and wealth, these explorers set

$2 \quad$ Department of Latin American and Caribbean Affairs Ministry of Foreign Affairs of China, April, 2016, "Basic Information about China-CELAC Forum"

3 Source: Ministry of Foreign Affairs of People's Republic of China

$4 \quad$ ECLAC, Press Release, 22 January 2018, "ECLAC Highlights Importance and Opportunity in Strengthening Ties between China and Latin America and the Caribbean" 
up Macao as one of the first outposts in the Far East to service this trade." 5 In 1557, Macau became the first European trading post in Asia when the Portuguese successfully obtained permission from the Ming Government for establishing a permanent settlement and trade base in Macau.

\subsection{Macau - Connection with the Latin World since the Age of Discovery}

Macau's long-established connection with the Latin world started during the Age of Discovery ( $15^{\text {th }}$ to $17^{\text {th }}$ Century). At that time Macau was functioning as an important hub for Portugal's trade along three major routes:

(1) Macau-Malacca-Goa-Lisbon;

(2) Guangzhou-Macau-Nagasaki;

(3) Macau-Manila-Mexico.

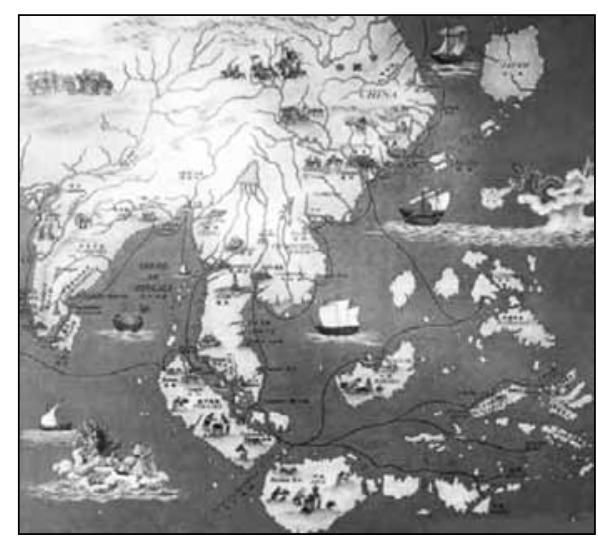

The Maritime Silk Route, based in Macau, expanded to reach Europe via Goa, Japan via Nagasaki, Spanish America via Manila, and Southeast Asia via Malacca. This was the first step of Globalization.

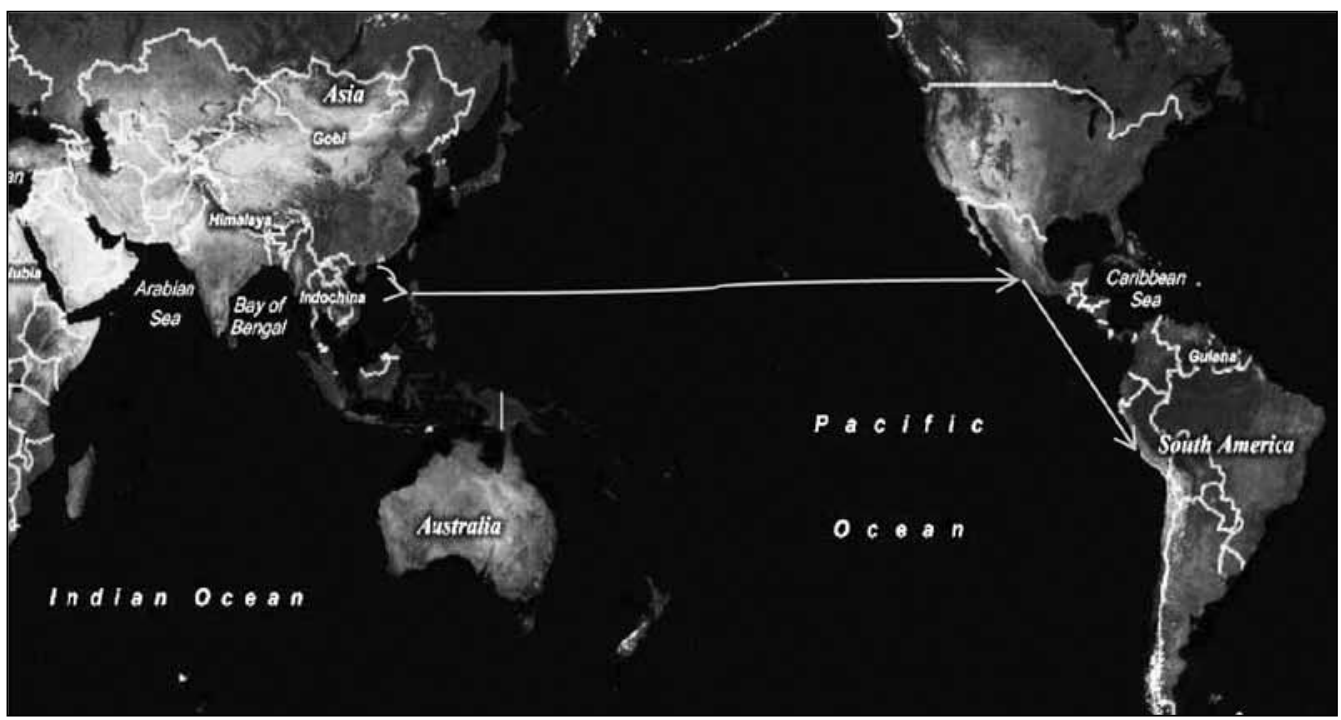

$5 \quad$ Alex H. Choi (2006) "Migrant Workers in Macao; Labour and Globalization", Transnational Migration and Work in Asia edited by Kevin Hewison, Ken Young, Part II, 9, 144-164 
The Macau-Manila-Mexico route brought to Macau and China, among all other products, "Tales of Silver from Mexico and Peru." It was during this period that Macau first started its bridging role in connecting China with Latin America, from Mexico to Peru and gradually to the other parts of the continent.

Starting from 1557, Macau has been under the administration of the Portuguese government for 442 years until December 1999, when this last Portuguese overseas enclave was officially returned to China and renamed as "Macao Special Administrative Region of the People's Republic of China". As agreed in the "Joint declaration of the Government of the People's Republic of China and The Government of the Republic of Portugal on the question of Macao" signed by the two governments on the $13^{\text {th }}$ April 1987, "the current social and economic systems in Macao will remain unchanged, so will the life-style. The laws currently in force in Macao will remain basically unchanged. Due regard will be given to the economic interests of Portugal and other countries in Macao. All these basic policies and principles would be provided for in the Basic Law of the Macao Special Administrative Region of the People's Republic of China and will remain unchanged for 50 years." "T The Joint Declaration expressed fully the principals of "One Country, Two Systems”, „Administration of Macao by the Macao People” and „a High Degree of Autonomy" in Macao. This innovative concept of "One Country, Two Systems" provided a pragmatic and flexible approach for Macau to start a new era, a better and more promising future!

\subsection{Macau's Cultural Characteristics}

After a substantial period of mixed influences, Macau has adapted itself into a city of high tolerance with a well-blended culture of the East and West. People of various races with different religious beliefs and cultures have co-existed in this small oriental city in harmony without major conflicts.

There is no doubt that after the last governor, the Basque General Rocha Vieira returned the enclave on $20^{\text {th }}$ December 1999 to China, and almost five centuries after its founding, Macau remains a unique ethnical and cultural piece in the global context, especially for tolerance and coexistence of civilizations. In the four and a half centuries of domination, Macau never held the category of colony, but "Chinese territory under Portuguese administration" with an identity that remains intact: Never was China, nor Portugal, but simply Macau.

Macau's cultural diversity can be well presented in five areas: Religion, Architecture, Miscegenation, Language and Cuisine:

$6 \quad$ Candice Goucher, Linda Walton (2008): “WORLD HISTORY, JOURNEYS: Journeys from Past to Present", 154

7 Ministry of Foreign Affairs of the People's Republic of China, Diplomatic History, Events \& Issues: "Resumption by China of the Exercise of Sovereignty over Macao". http://www. fmprc.gov.cn/mfa_eng/ziliao_665539/3602_665543/3604_665547/t18052.shtml 


\subsubsection{Religion}

It is on this tiny piece of land that "Bible" was first translated into Chinese. Also, it was the city where the first western style university (St. Paul's College) in the Far East was established by the Jesuits in $1594^{8}$. Catholicism is the most influential religion in Macau. The Catholic Church in Macau has long been serving as a bridge between Chinese and Western cultures as well as for linking up the mainland Church with the Lusophone Churches in Africa, Asia and Latin America. Nonetheless, a high degree of Religious Freedom could have been maintained successfully in the community without much difficulty. Catholicism, Christianity, Buddhism, Taoism, Confucianism, Muslim, Hindu, Bahai, etc. have been co-existing in this city in harmony for over centuries.

\subsubsection{Architecture}

Another cultural characteristic of Macau can well be seen around the city, i.e. the different architectural styles like Western, Chinese and Fusion. Indeed, "The Historic Centre of Macao", which was officially listed as a World Heritage Site by UNESCO including about twenty-five historic locations, is the living testimony to the integration and co-existence of eastern and western cultures over centuries.

\subsubsection{Miscegenation - Macanese Identity}

The term miscegenation has been used since the $19^{\text {th }}$ century to refer to interracial marriage and has entered historical records during European colonialism and the Age of Discovery. Macanese - the early Macanese ethnic group was formed from intermarriages between Portuguese men and Malay, Japanese or Indian women. The Portuguese also encouraged Chinese migration to Macau and most Macanese in Macau were then formed from intermarriages between Portuguese and Chinese. "After the handover of Macau to China in 1999 many Macanese migrated to other countries. There are between 25,000-46,000 Macanese, but only 5,000-8,000 are living in Macau, while most are living in Latin America, America and Portugal." 9

\subsubsection{Language}

Having been influenced substantially by Portugal for almost four and a half centuries, Macau can be considered as the most open city in China for accepting the use of Latin languages in the community when compared with other places in the Mainland. It is no surprise that Macau is the only place in China where three languages (Chinese, Portuguese and English) and four dialects (Cantonese, Mandarin, Portuguese and English) are in use and are incorporated into the

8 Cathryn H. Clayton (2009): "Sovereignty at the Edge: Macau \& the Question of Chineseness", 146-147, Harvard University Asia Center

9 Dr. Robert H. Schram (2013): Mixed Marriage...Interreligious, Interracial, Interethnic. 129 
elementary and secondary education system. While Chinese and Portuguese are the two official languages, English is another widely spoken language in the city mainly for business and tourism. In general, students are exposed to 2 to 3 languages at an early age.

\subsubsection{Cuisine and Tourism}

Long before the term fusion was invented it had already been cooked up in this former Portuguese outpost. The characteristic flavors of China and Portugal are combined in the native Macanese cuisine. Nevertheless, the Macanese cuisine involves other foreign influences as well. The Portuguese mariners, who arrived in Macau from their travels, brought along with them the tastes of Europe, Latin America, Africa, India and Southeast Asia, creating a unique and delicious fusion cuisine that eventually became a famous attraction of Macau. In 2017, Macau was awarded the designation of "Macao, China" as a new member city of UNESCO Creative Cities Network (UCCN) in the field of Gastronomy by the UNESCO. "This title reflects the global recognition of Macau's 400-plusyear old culinary legacy and the increasing interest among the young generation in gastronomy culture and especially Macanese cuisine. It will also provide favorable conditions for food traditions to continuously thrive". ${ }^{10}$

Macau has a relatively long history of tourism industry development. Without doubt, Macau's tourism industry has been closely linked with gaming which was legalized by the Portuguese Macau government since 1850s. "In February 1961, the $119^{\text {th }}$ Governor of Macao Jaime Silvério Marques designated Macao as a "permanent gaming region" and officially positioned Macao as a low taxation region and regarded gaming and tourism as its major economic activities."11 In the following year, when the Sociedade de Turismo e Diversoes de Macau (STDM) won the bidding and got the monopoly concession, Macau tourism industry entered a new era of expansion. Nevertheless, the gaming monopoly eventually came to an end in 2002 for the aim of injecting new dynamics to the industry. Following the liberation from the gaming monopoly and the relaxation of "Hong Kong and Macao Tour" regulations by the Central Government in the same year, the tourism industry started to take an even bigger leap. In the past two decades, tourist resources and establishments developed rapidly, making Macau the World's No. 1 Gaming Capital and an international tourism city. Visitors soared from $11,530,841$ in 2002 to $32,610,506$ in $2017 .{ }^{12}$ By place of

$10 \quad$ Macau Daily Times, November 2, 2017, “MACAU DESIGNATED 'CREATIVE CITY OF GASTRONOMY’ BY UNESCO” https://macaudailytimes.com.mo/macau-designatedcreative-city-gastronomy-unesco.html

11 The Gaming Inspection and Coordination Bureau of Macau SAR government, "Macao Gaming History", http://www.dicj.gov.mo/web/en/history/index.html

12 Statistics and Census Service of Macau SAR government, http://www.dsec.gov.mo/home. aspx?lang=en-US 
origin, visitors from mainland China accounted for almost 22.2 million, while those from Hong Kong around 6.16 million and Taiwan 1.06 million (Figure 1).

Figure 1. Visitors to Macau by Origin in 2017

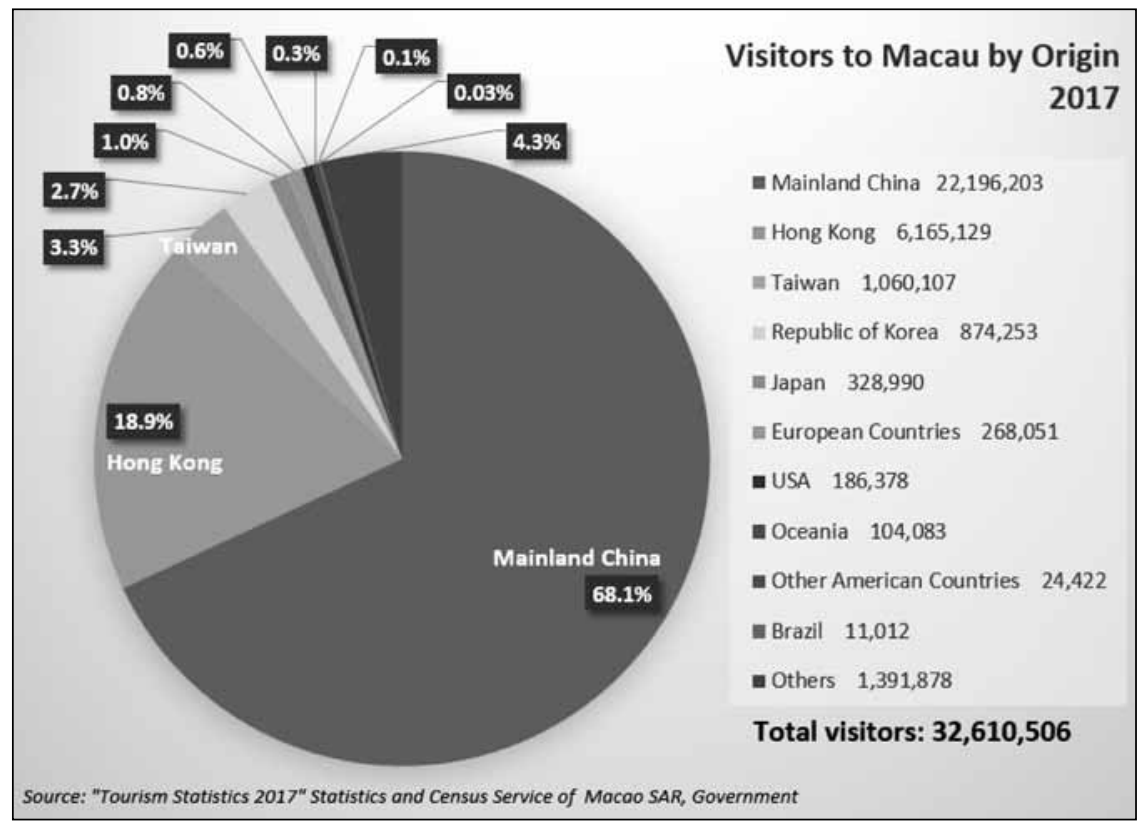

The visitor-source markets however need to be more diversified and tourists from the Americas, Europe and other places should be encouraged to come and explore this special oriental city. To avoid over-dependence on a single industry sector - gaming, Macau has been striving to develop cultural tourism manifesting the city's cultural heritage such as the World's Heritage Sites and her unique culinary legacy. Indeed, more and more visitors are attracted to Macau, not only by gaming but also by the Macanese cuisine and the exquisite dinning ambiance.

Owing to all these historical and cultural characteristics, Macau is close to the Latin world, not by physical distance but by the feeling of familiarity and perceived similarity! In essence, these special features, in toto, make it comparatively easier for Macau to get connected with the Latin countries. In practice, Macau has a great capacity for linking up China with Latin America, specifically in the realms of business and cultural exchange, not only in the past but also at the present and in the future! 


\section{Macau - Special Administrative Region of the People's Republic of China (PRC)}

Macau has been administered by Portugal from the mid-16th century until late 1999, when it was the last remaining European enclave in Asia. Sovereignty over Macau was transferred back to China on 20 December 1999. The SinoPortuguese Joint Declaration and the Basic Law of Macau stipulate that Macau operates with a high degree of autonomy until at least 2049, fifty years after the transfer. ${ }^{13}$ Since then, Macau has become one of the two Special Administrative Regions of China, similar to its neighbor Hong Kong.

Macau or the Macau Special Administrative Region (MSAR) is a highly autonomous city located on the western side of the Pearl River Delta, one of the most important economic regions in the Southern China, bordering Guangdong Province and is about $60 \mathrm{~km}$ from Hong Kong. Similar to many small cities, Macau is rarely the center of attention in the global issues and therefore sounds unfamiliar to most of the people in the world.

Macau consists of the Macau peninsula, the Taipa Island and the Coloane Island. Due to city development, the two islands are currently linked by the COTAI Reclamation Area. Through land reclamation, the total land area of Macau has gradually increased from 11.6 square kilometers in 1912 to 30.5 square kilometers as of today. As per the results of the 2016 Census, the population of Macau is about

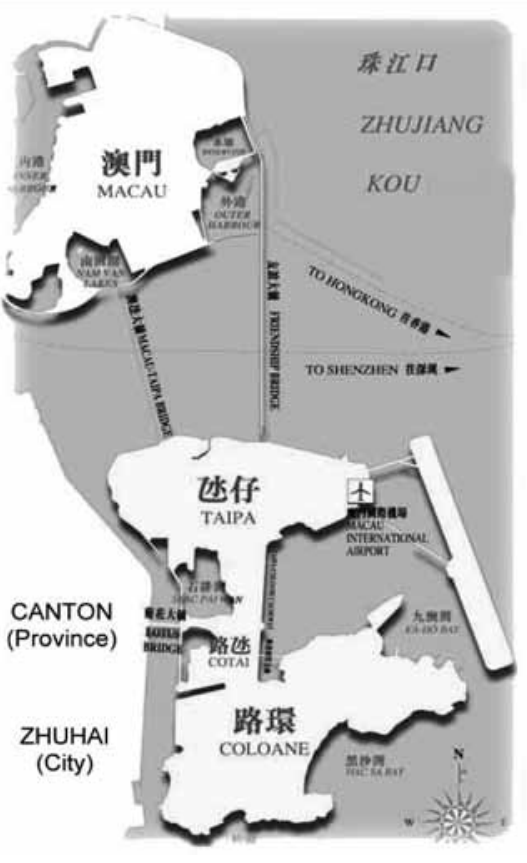
$650,834 .{ }^{14}$ Among the population, $88.4 \%$ were Chinese, $1.4 \%$ Portuguese, and $4.6 \%$ percent Filipino. ${ }^{15}$

According to the World Bank, Macau is one of the world's richest cities, with the highest GDP per capita by purchasing power parity as of $2015 .{ }^{16}$ Macau's

13 University of Macau, "Basic Law of the Macao Special Administrative Region of the PRC", 26 May, 1998.

14 Statistics and Census Service of Macau SAR government, " INTERCENSOS 2016 RESULTADOS GLOBAIS”, 2016.

15 Statistics and Census Service of Macau SAR government, " INTERCENSOS 2016 RESULTADOS GLOBAIS”, 2016.

16 World Development Indicators database, Retrieved 15 September 2014, "GDP per capita, PPP (current international \$)" 
gross domestic product (GDP) was 325.2 billion Patacas. This translates into 574,798 Patacas or US $\$ 71,894$ of GDP per capita - one of the highest in Asia. ${ }^{17}$

The gaming and the tourism industries are the major driving forces of Macau's economy. The largest source of direct tax for the local government is from Gaming Industry. Macau became the world's largest gambling center in 2006. ${ }^{18}$ According to statistics provided by the Gaming Inspection and Coordination Bureau (DICJ), the gaming industry's total gross revenue in 2013 amounted to 360 billion Patacas (US $\$ 46.25$ billion), ranking No. 1 in the world. In 2017, though the gross revenue of gaming has dropped, it still remained at a high level of about 265.7 billion Patacas (US\$33.13 billion). ${ }^{19}$

Besides gaming, tourism is another important economic sector of Macau. In 2017, the total number of visitors to Macao hit $32,610,506 .{ }^{20}$ In accordance with the government strategy, Macau is striving to develop into a Tourism and Gaming, MICE \& Leisure Destination. Apart from gaming, cultural tourism is another element that Macau want people to get attracted to. Macau is not only a casino city, as described by some sources, but also a city rich in history and cultural specialties. "In 2005, The Historic Centre of Macao was inscribed on the UNESCO World Heritage List as a result of its unique historical and cultural landscape". ${ }^{21}$ In November 2017, Macau was also officially designated a member of the UNESCO Creative Cities Network in the field of Gastronomy. ${ }^{22}$

Apart from its historical and cultural characteristics, what are the other elements that made Macau different from other mainland cities and comparatively well-prepared for the China-Latin American connection? Without doubt, the status of Special Administrative Region and the Support of the Central Government are the keys to success!

As a special administrative region, Macau enjoys a good number of special and exclusive privileges that help differentiate itself from other cities in mainland China. With special arrangement, Macau is in a more favorable position to perform the bridging role between China and the Latin World. Among many, the main privileges are: High Degree of Autonomy, Open Economy, Free Port, Low Tax Rate and Different Legal System.

\footnotetext{
17 World Development Indicators database, Retrieved 15 September 2014, "GDP per capita, PPP (current international \$)"

18 Barboza, David (2007-01-23). "Macao Surpasses Las Vegas as Gambling Center". The New York Times.

19 The Gaming Inspection and Coordination Bureau of Macau SAR government, "Monthly Gross Revenue from Games of Fortune in 2017 and 2016"

20 Statistics and Census Service of Macau SAR government, http://www.dsec.gov.mo/home. aspx?lang=en-US

21 http://en.macaotourism.gov.mo/plan/aboutmacao.php

22 https://en.unesco.org/news/64-cities-join-unesco-creative-cities-network
} 


\subsection{Business Platform for Exploring Opportunities in Mainland China}

High Degree of Autonomy - Under the policy of "One Country, Two Systems", the PRC's Central People's Government is responsible for the territory's defense and foreign affairs, while Macau maintains its own legal system, police force, monetary system, customs policy, and immigration policy. Macau participates in many international organizations and events that do not require members to possess national sovereignty. ${ }^{23}$

By enjoying high degree of autonomy and freedom in different aspects, Macau is highly flexible and capable of performing its bridging role between mainland China and the rest of the world, especially in its connection with the Latin speaking countries.

According to the Basic Law, Macau may develop bilateral relations with other countries or regions and participate in international organizations and multinational treaties on its own under the name 'Macao, China' in the areas of commerce, trade, finance, aviation, communication, tourism, culture, technology and sport.

As per the information given by the Macau government, by the end of 2013, 89 countries established consular services in Macau or extended their consular services from Hong Kong to Macau. Portugal, Angola and the Philippines have established their Consulates General to provide full consular services directly in Macau. Fifty-three Consulates General accredited to Hong Kong are also covering Macau and some of the Latin American Consulates General also execute consular duties in Macau such as Argentina, Brazil, Chile, Columbia, Mexico, Peru and Venezuela.

At the moment, certain Latin American and Caribbean countries are still reluctant to build up official ties with mainland China due to different political or non-political reasons. In this regard, Macau is in fact holding a special and pivotal position that can help accommodate the needs and take the necessary steps forward for bringing those Latin American countries closer to China by means of city diplomacy or more frequent non-political cooperation that would bring about mutual benefits to all parties involved.

Open Economy and Free Port - For those who are striving to explore business opportunities or to establish closer economic relations with the mainland, Macau as a special administrative region can serve as a doorway or a desirable destination for the start-ups. Taking advantage of Macau's special and privileged business environment, the Latin American and Caribbean enterprises may enjoy a good number of attractive conditions that are available solely in Macau, but not in other mainland cities.

23 University of Macau, "Basic Law of the Macao Special Administrative Region of the PRC", 26 May, 1998. 
Macau adopts an open and free market economic system. With its openness and flexibility, Macau enjoys a unique position in the regional economy. Being one of the two international free ports in China, goods, capital and people can move freely in and out of Macau.

In May 2013, the World Trade Organization (WTO) released a trade policy review of Macao reaffirming the openness of Macau's economy, with its zerotariff policy and minimum trade and investment restrictions. The report affirmed Macau's improvements in trade policies and business environment, including enhancement of the intellectual property rights system, further opening of the services industry, and facilitation of trade. According to the 2016 Index of Economic Freedom released by the US-based Heritage Foundation, Macau was ranked 7 th in the Asia-Pacific region and ranked $37^{\text {th }}$ among 178 economies globally and is considered a "mostly free" economy.

Low Tax Rate - Macau is having one of the lowest tax regimes in the Asia Pacific region. Assessable profit up to 200,000.00 Macau Patacas (US\$25,000.00) is tax-free and assessable profit over that amount is taxed at progressive tax-rate ranging from $9 \%$ to $12 \% .{ }^{24}$ The first 144,000 Macau Patacas (MOP) of an individual's taxable income is exempt from Macau Professional Tax. Progressive tax rates range from $7 \%$ to $12 \%$. Income earned over MOP 424,000 is taxed at $12 \% .{ }^{25}$

Different Legal System - Under the principle of "One country, two systems", the Macau Special Administrative Region maintains the Continental European law as the foundation of its legal system. The Basic Law gives Macau independent judicial power, including the power of final adjudication. Macau's legal system strongly adheres to the rule of law and judicial independence. The courts exercise independent judicial power and are subordinated to nothing but the law.

The Basic Law, the constitutional document for Macau, adopted by the National People's Congress (NPC) in accordance with the Constitution of the People's Republic of China (PRC), safeguards the fundamental rights of the people of Macau including the freedom of speech, freedom of the press, freedom of association and assembly, freedom of procession and demonstration, the right to organize and join trade unions and to strike, freedom of religion, freedom to travel, and freedom to enter and leave Macau. Provisions applicable to Macau in the International Covenant on Civil and Political Rights, the International Covenant on Economic, Social and Cultural Rights and a number of international labor conventions also remain in force. In addition, Macau continues to comply with the main international conventions on human rights in different aspects.

24 The Deloitte International Tax Source (DITS), "Macao Highlights 2014", https://dits. deloitte.com/\#TaxGuides

25 KPMG International Cooperative, 1 Mar 2017, "Macau-Thinking Beyond Borders"https:// home.kpmg.com/xx/en/home/insights/2014/04/macau-thinking-beyond-borders.html, 
Based on this special arrangement, one of the advantages of doing business in Macau is undoubtedly the comprehensive legal system that "maintains the Continental European law as the foundation of its legal system". 26 This provides a different legal origin that is considered, to certain extent, more favorable to international companies. In addition, Macau can serve equally well as an international arbitration center in the region.

\subsection{The Mainland and Macau Closer Economic Partnership Arrangement (CEPA)}

The Mainland and Macau Closer Economic Partnership Arrangement, or Closer Economic Partnership Arrangement (CEPA) for short, is an economic agreement signed officially on October 17, 2003 between the local government of the Macau Special Administrative Region and the Central People's Government. ${ }^{27}$ CEPA covers four main areas: trade in goods, trade in services, investment, economic and technical cooperation.

CEPA offers Macau's products and companies' preferential access to the mainland's market. CEPA goes beyond China's World Trade Organization (WTO) commitments, eliminating tariffs and allowing earlier or preferential access to some service sectors. Overseas companies may benefit from CEPA in the following way:

- For trade in goods, foreign investors can set up production lines in Macau to produce goods that meet the CEPA "Rules of Origin" requirements or partner with a manufacturer whose products satisfy the CEPA 'Rules of Origin'.

- For trade in services, companies incorporated in Macau by foreign investors can make use of CEPA as long as they satisfy eligibility criteria of a "Macau Service Supplier" (for example, they must have a three to five-year operating history, depending on the sector or by partnering with or acquiring a CEPAqualified company).

As long as the companies satisfy the criteria, they can easily gain benefits from CEPA. This favorable arrangement empowers Macau to become a more feasible and attractive platform for foreign companies which are interested in expanding their businesses into China.

26 Government Information Bureau of Macau, Jun 2017, ”The Legal and Judiciary System", http://www.gcs.gov.mo/files/factsheet/Law_EN.pdf

27 The Macao Economic Bureau of Macau SAR government, 17 Oct 2003, "Mainland and Macao Closer Economic Partnership Arrangement" (CEPA) http://www.economia.gov. mo/public/docs/CEPA_CEPA_I/index/en/efulltext.pdf 


\subsection{Economic Cooperation and Integration with Mainland Cities - PRD Economic Zones and Greater Bay Area}

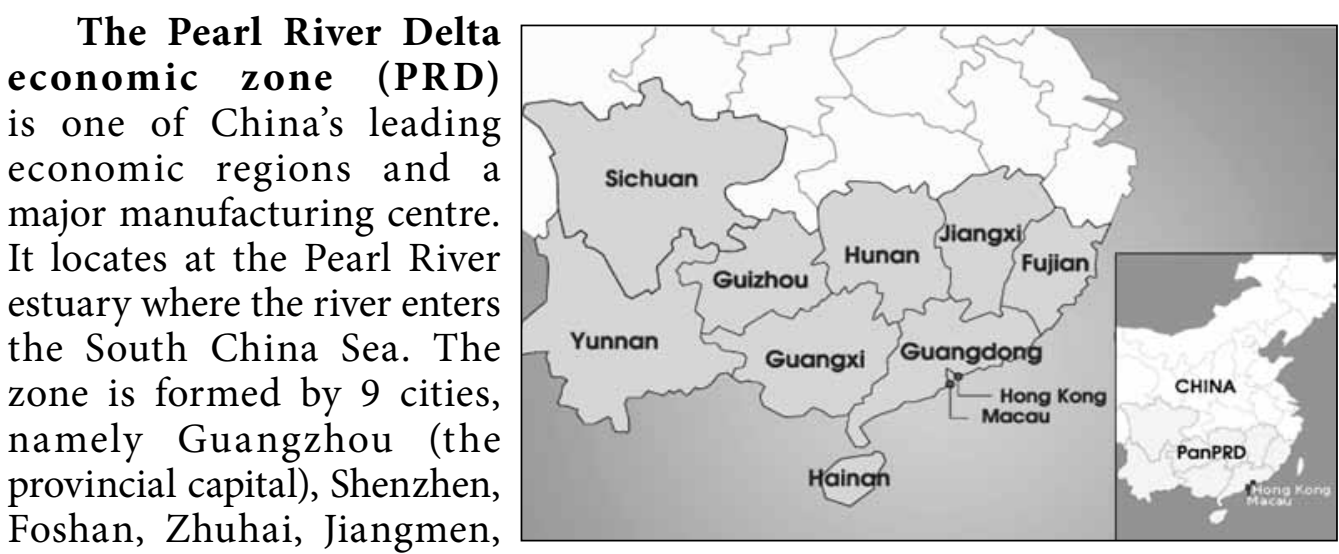

Zhongshan, Dongguan, four districts and counties of Huizhou and four districts and counties of Zhaoqing. ${ }^{28}$

PRD is one of the mainland's largest and most sophisticated consumer markets. Strong demand for consumer goods is driven by the growing income and influx of tourists. In 2015, PRD enjoyed a per capita GDP of RMB 107,011, 2.2 times of the national average of RMB 49,992. With $4.3 \%$ of China's total population, the region accounted for $7.5 \%$ of the nation's total retail sales of consumer goods. Retail sales of consumer goods in the region reached RMB $2,265.1$ billion in 2015, that is a growth by $9.7 \%$ from 2014. Major consumer markets are in Guangzhou and Shenzhen. ${ }^{29}$ This region is often considered as an emerging megacity and is one of the richest economic zones in China.

The Pan Pearl River Delta region (Pan-PRD), on the other hand, is a concept of economic co-operation of the largest scale ever since the establishment of People's Republic of China. In terms of administrative region, the Pan Pearl River Delta region includes Fujian, Jiangxi, Hunan, Guangdong, Guangxi, Hainan, Sichuan, Guizhou, Yunan Provinces or Autonomous Administrative Regions, and Hong Kong, Macao SARs. Thus it can be sometimes referred as "nine plus two". The total area covered is 2 million square kilometres, $20.9 \%$ of the total national surface, with the population of 0.45 billion $(34.8 \%$ of total

28 Hong Kong Trade Development Council, 2 Dec 2016, "PRD Economic Profile", http:// china-trade-research.hktdc.com/business-news/article/Facts-and-Figures/PRDEconomic-Profile/ff/en/1/1X000000/1X06BW84.htm

29 Hong Kong Trade Development Council, 2 Dec 2016, "PRD Economic Profile”, http:// china-trade-research.hktdc.com/business-news/article/Facts-and-Figures/PRDEconomic-Profile/ff/en/1/1X000000/1X06BW84.htm 
Chinese population), and the GDP of RMB 3,884.6 billion that is one third of the national total GDP. ${ }^{30}$

Guangdong-Hong Kong-Macao Bay Area (or Greater Bay Area/Big Bay Area) - is an advanced version of the Pearl River Delta and the Pan-Pearl River Delta development initiatives. In July 2017, the National Development and Reform Commission, the Hong Kong Special Administrative Region Government, the People's Government of Guangdong Province and the Macao Special Administrative Region Government signed a "Framework Agreement on Deepening Guangdong-Hong Kong-Macao Cooperation in the Development of the Bay Area" in Hong Kong - "To fully leverage the integrated advantages of the Guangdong, Hong Kong and Macao region, deepen cooperation amongst Guangdong, Hong Kong and Macao, take forward the development of the Guangdong-Hong Kong-Macao Bay Area, participate in international cooperation at a high level, enhance the leading role in the nation's economic development and comprehensive opening up, provide new impetus to the development of Hong Kong and Macao, and maintain the long-term prosperity and stability of Hong Kong and Macao." 31

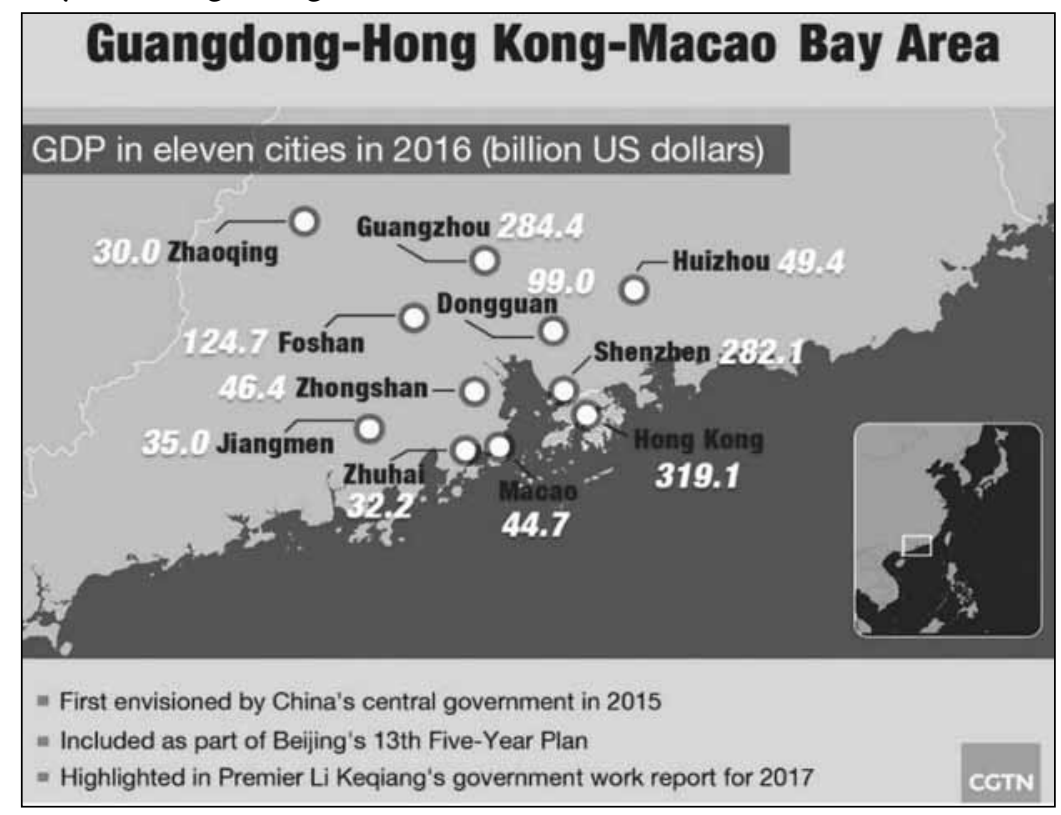

30 Macao Trade and Investment Promotion Institute, Jun 2004,“The Co-operation and Development of Pan Pearl River Delta",http://www.ipim.gov.mo/pt/publication/ newsletter/213/213_1.htm

31 Constitutional and Mainland Affairs Bureau, Hong Kong SAR Government (2017) "Framework Agreement on Deepening Guangdong-Hong Kong-Macao Cooperation in the Development of the Bay Area"http://www.cmab.gov.hk/doc/issues/bay_area/ Framework_Agreement_e.pdf 
The Greater Bay Area connecting Hong Kong, Macao and nine cities in Guangdong province (Guangzhou, Shenzhen, Foshan, Dongguan, Zhuhai, Huizhou, Zhongshan, Jiangmen, and Zhaoqing) has been listed as one of the country's top three regions of strategic importance.

"The combined regional GDP of the Greater Bay Area stood at RMB 9.35 trillion (1.38 trillion U.S. dollars) in 2016 (Table 1), compared with the GDP of the Chinese mainland at RMB 74.41 trillion last year. Estimates show the regional GDP of the Greater Bay Area will reach 4.62 trillion U.S. dollars by 2030, surpassing Tokyo, New York and San Francisco bay areas to become the world No. $1 .{ }^{32}$

Table 1. Guangdong-Hong Kong-Macao Greater Bay Area Regional GDP and Population

Guangdong-Hong Kong-Macao Greater Bay Area (9+2)
Year: 2016
\begin{tabular}{|l|r|r|r|}
\hline \multicolumn{1}{|c|}{ Region/City } & $\begin{array}{c}\text { GDP } \\
\text { (Billion US\$) }\end{array}$ & $\begin{array}{c}\text { GDP per } \\
\text { Capita } \\
\text { (US\$) }\end{array}$ & $\begin{array}{c}\text { Population } \\
(10,000)\end{array}$ \\
\hline Macao (SAR) & 44.70 & 70,160 & 64 \\
\hline Hong Kong (SAR) & 319.10 & 43,681 & 735 \\
\hline Shenzhen & 282.10 & 25,789 & 1,191 \\
\hline Guangzhou & 284.40 & 21,868 & 1,404 \\
\hline Zhuhai & 32.20 & 20,511 & 168 \\
\hline Foshan & 124.70 & 17,485 & 746 \\
\hline Zhongshan & 46.40 & 15,023 & 323 \\
\hline Dongguan & 99.00 & 12,453 & 826 \\
\hline Huizhou & 49.40 & 10,802 & 478 \\
\hline Jiangmen & 35.00 & 8,057 & 454 \\
\hline Zhaoqing & 30.00 & 7,728 & 406 \\
\hline Source: Municipal Statistic Bureaus, World Bank national accounts data, & \\
\hline OECD National Accounts data files, www.elivecity.com & &
\end{tabular}

According to the Chinese government's scheme, the creation of this mega city cluster will have impacts beyond the area, given the important development platforms, major infrastructure projects and significant economic and trade cooperation that are being or going to be involved. The Guangdong-Hong Kong-Macau Bay Area is poised to be a landmark in the country's comprehensive reform process as well as an integrated economic and business hub in southern China.

32 "China plans world-leading bay area covering Guangdong, HK, Macao", Xinhua, 11 July
2017, http://www.xinhuanet.com/english/2017-07/11/c 136435539.htm 
Macau, being part of this mega region of key strategic importance, can benefit from the synergy created by the whole structure and play a more active role in bridging China and the different Latin American countries.

\section{Macau's Logistic Network with the Mainland and the Outside World}

Air-Land-Sea Transportation - though Macau is a small city, it is well equipped with an international airport, container harbor, 24-hour ferry terminals, bridges and roads for connecting with different mainland and overseas cities. The point of interest here is the capacity of the Macau International Airport which is still not fully utilized and is ready to handle more flights and cargo transactions not only for the city itself but also for the nearby cities. By opening new routes between Macau and Australia/New Zealand, Macau can well serve as a link between China and Latin America in the Pacific Rim for accommodating the increasing demand for air freights and cargo transactions between the two regions.

By combining with the land and sea transportation infrastructure and facilities, cargos or passengers arriving at the Macau International Airport from Australia, New Zealand or Latin America can easily be transferred to the different parts of China, especially on the Pan-Pearl River Delta and the Greater Bay Area. Outbound passengers and cargos from Macau and China, along with the same routes, can also be transferred easily to the other overseas cities.

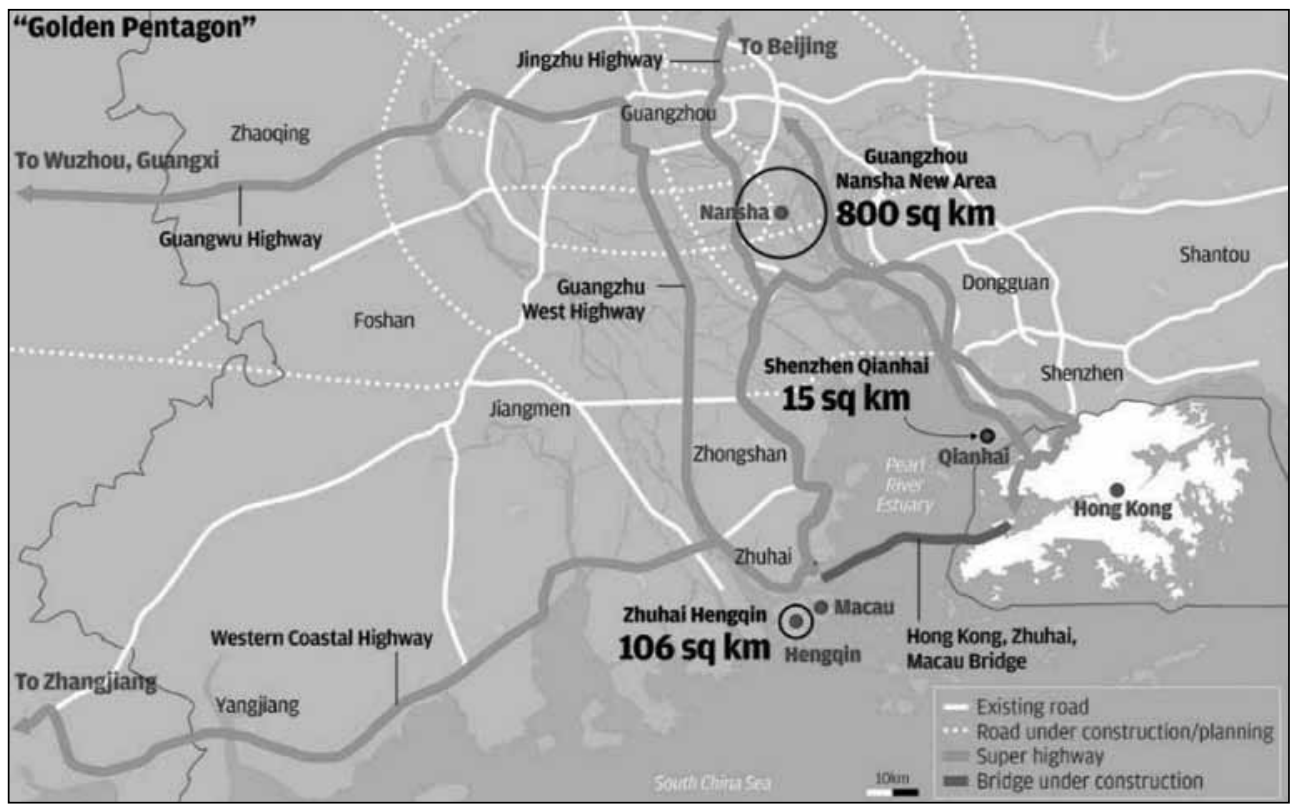


Hong Kong- Macau- Zhuhai Bridge - the British newspaper "The Guardian” named this new mega structure one of its "seven wonders of the modern world near completion." According to www.theguardian.com, the new Hong KongZhuhai-Macao Bridge is "A new road link under construction combining long bridged sections with cable-stayed spans and an immersed tunnel, the mouths of which are housed on new artificial islands, it'll take the title of the longest water span in the world".

The Hong Kong-Zhuhai-Macao Bridge (HZMB), being situated at the waters of Lingdingyang of Pearl River Estuary, is a mega-size sea crossing linking the Hong Kong Special Administrative Region (HKSAR), Macau Special Administrative Region and Zhuhai City of Guangdong Province.

It consists of a Main Bridge in Mainland waters together with the boundary crossing facilities and link roads within the three places. The functions of the Bridge are to meet the demand of passengers and freight land transport among Hong Kong, the Mainland (particularly the region of Pearl River West) and Macau, to establish a new land transport link between the east and west banks of the Pearl River, and to enhance the economic and sustainable development of the three places. The project includes a $29.6 \mathrm{~km}$ dual 3-lane carriageway in the form of bridge-cum-tunnel structure comprising a tunnel of about $6.7 \mathrm{~km} .{ }^{33}$

The bridge will cut the travel time from Hong Kong to both Macau and Zhuhai from the current one hour by sea or three hours by road to a half hour drive. This new wonder will certainly facilitate the transfers of both passengers and cargos between Hong Kong, Macau and Zhuhai which in turn will help build a much stronger logistic network in the Greater Bay Area.

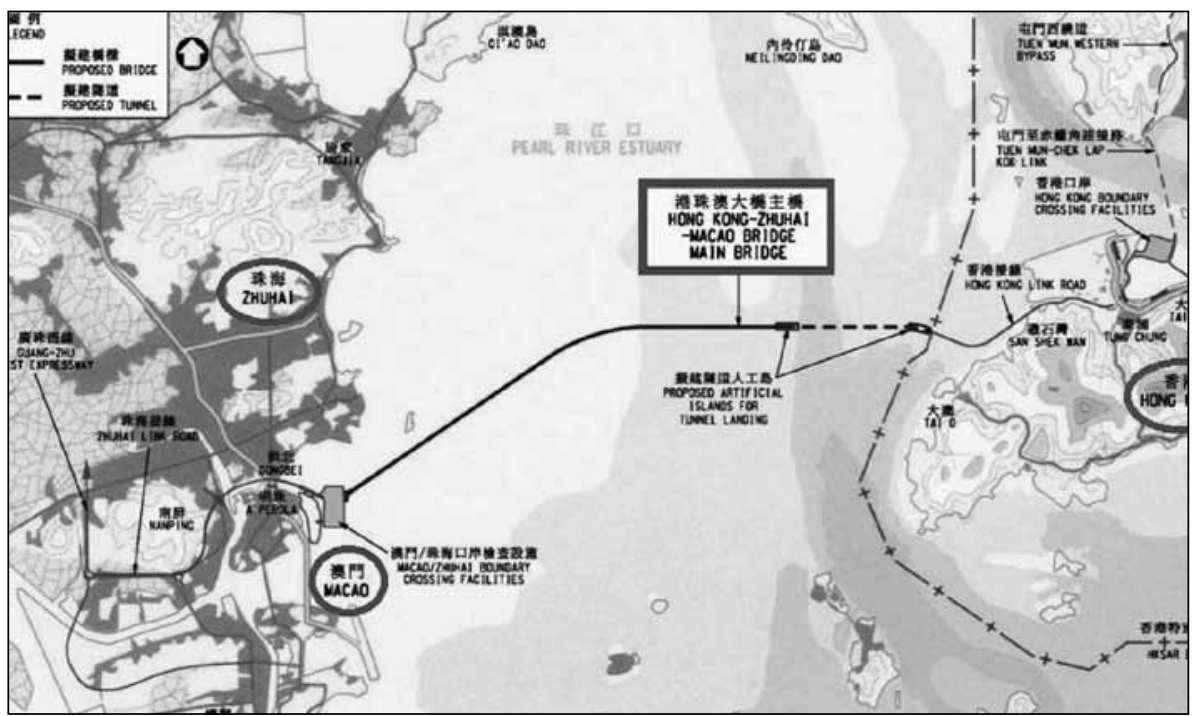

33 Hong Kong - Zhuhai - Macao Bridge Hong Kong Project Management Office, 2010, "Project Overview".http://www.hzmb.hk/eng/about_overview_01.html 
As a portal, connected with this new mega-size bridge and a vast logistic and infrastructure network, Macau can further capitalize on its core strengths to become a strong logistic and business hub between China and Latin America via Australia or New Zealand in the Pacific rim.

\section{Extension of One Belt One Road to Guangdong-Hong Kong-Macao Bay Area}

With the open endorsement and blessing of President Xi Jinping, the Guangdong-Hong Kong-Macao Bay Area (Greater Bay Area) is officially linked with the One Belt One Road Initiative. The Greater Bay Area is not only considered as the most international region in China but also an area capable of becoming one of the vital portals for the Belt and Road. Embraced with about 66 million people and a combined GDP of around 12 percent of China's total GDP, the Greater Bay Area is in a relatively high position in the international value chain, especially when taking into account the two free ports of Hong Kong and Macau.

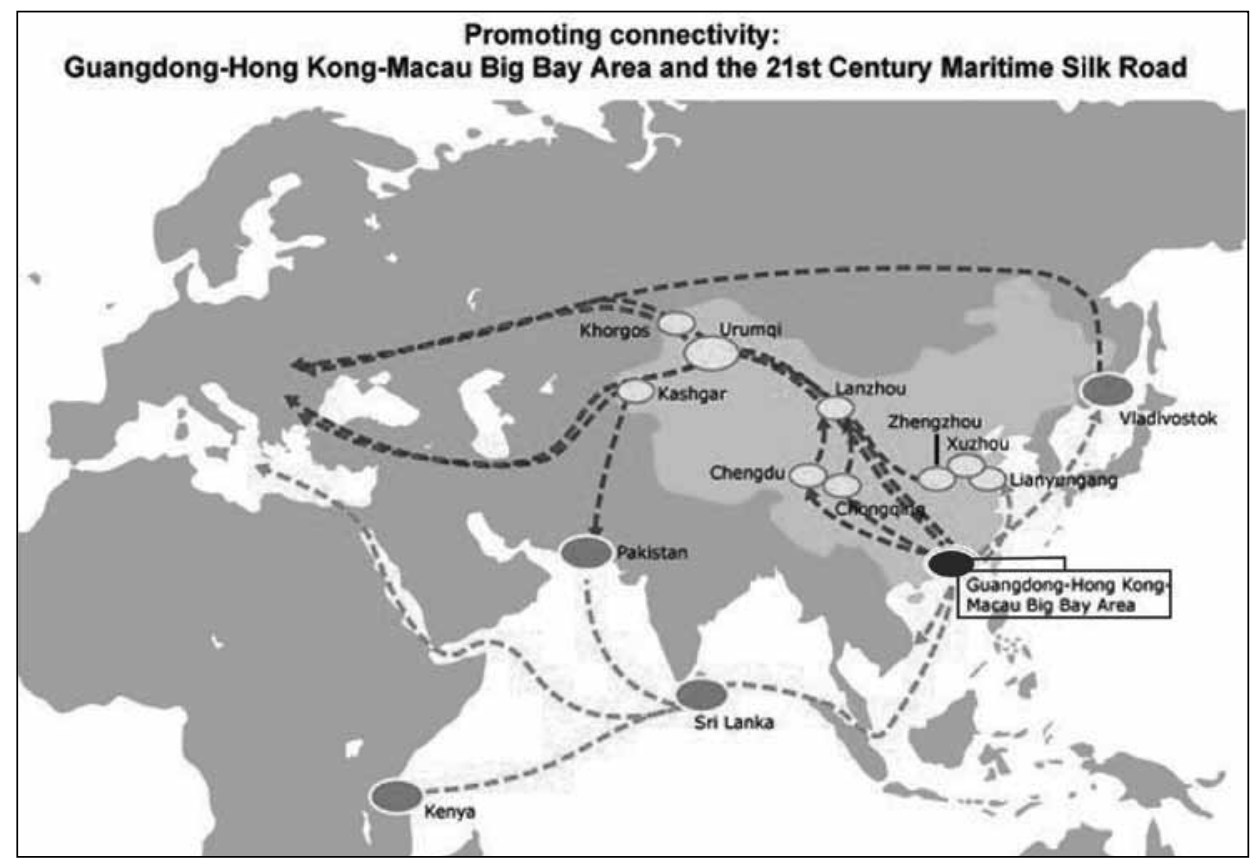

By connecting the Greater Bay Area with Latin America via the air routes in the Pacific rim, preferably between the airports of Australia/New Zealand and Macau, it is very likely to give rise to an extended version of the Belt and Road Initiative. This extension will involve more cities to the Belt and Road, not just by land and sea links but also by air. In a world that values win-win cooperation 
on a par with the traditional Chinese cultural values of "peace and cooperation", this extension will definitely help bring mutual benefits to the parties involved on the basis of peaceful coexistence.

\section{Strengthening Links with Latin America through Macau NGOs}

It is widely recognized that socio-cultural and economic exchanges are the initial steps for establishing or strengthening links between two places without carrying on board heavy political burdens. By enjoying the freedoms granted by the Central Government, socio-cultural and economic exchanges between China and the Latin American and Caribbean countries can be carried out in Macau with much flexibility and high efficiency.

In fact, interactions between Macau and number of Latin American and Caribbean (LAC) countries have increased significantly in the past decade. With the support of the local government, NGO like MAPEAL (Macao Association for the Promotion of Exchange between Asia-Pacific and Latin America) has been striving to enforce the bridging role of Macau between China and Latin America. Events and activities of low politics such as in the areas of business, culture, academic and tourism have been organized regularly and frequently in Macau for connecting the LAC countries closer to China.

In September 2007, MAPEAL has hosted the $13^{\text {th }}$ Congress of FIEALC in Macau with the support of the local government. It was the first time for Macau to have received over 400 academics and intellectuals coming from 34 countries for in-depth discussions about Latin America and the world.

In the field of business, MAPEAL has been organizing the "Latin American Pavilion" and Business Forums at the biggest local annual event, the "Macao International Trade and Investment Fair" (MIF) since the year of 2008 for the promotion of business links between the two regions. With the support of the local government and the collaboration of the Embassies in Beijing and the Consulates General in Hong Kong, Macao and Guangzhou, the "Latin American Pavilion" has been promoting the different Latin American and Caribbean products and services to the local community as well as to the fair visitors from all over the world.

In 2017, countries participated in the "Latin American Pavilion" were Argentina, Brazil, Bolivia, Chile, Colombia, Cuba, Ecuador, Mexico, Panama, Peru, Uruguay and Venezuela.

On the cultural front, events like the "Latin American Cultural Festival" and the "Parade through Macao, Latin City" have already become two major cultural events for the promotion of the Latin cultures in Macau. National cuisines, cultural seminars, literary works, films, artworks, dance and music performances of different Latin American and Caribbean countries have been 
presented in the city for the purpose of encouraging more extensive cultural interactions between the two regions.

As the only association in Macau devoted to the promotion and strengthening of links between China and the Latin American and Caribbean countries, MAPEAL keeps exerting every effort to carry out its missions and achieve its goals. As we know, not only is it necessary to build up an optimal relation between the two regions, but also to have it maintained well into the future!

\section{Conclusion}

There is no doubt that Latin America has reinforced progressively its international position at the beginning of XXI century and successfully diversified contacts with the new political and economic partners in the contemporary world. On the other side, we could also note that China's interests in Latin America are increasing in the domain of investments, commerce and cooperation in security and defense questions. Consequently, China cooperates in the field of energy, copper, food products and commodities in general. In any case, all this indicates that China's policy towards Latin America is notably pragmatic and in line with its internal increasing needs as a result of accelerated economic growth and intensive global international strategy of expanding economic, political and cultural influences. In this context, Macau as a Special Administrative Region with high level autonomy inside China could be transformed strategically into an important and active player especially with Latin American countries.

There is a concrete basis for these arguments. Historically, Macau has been a Portuguese trading post in the Far East for over 442 years. After the Handover in 1999, Macau was officially returned to China as a Special Administrative Region. At present, Macau is the "world's top gaming capital" and a part of the Greater Bay Area of national strategic importance in southern China.

As depicted above, Macau is inherited with a unique historical and cultural background as well as gifted with some extra privileges because of its special status in the country which subsequently made itself quite different from the other mainland cities in China. By capitalizing on her core strengths and special privileges, Macau can go much further, not only as a gaming and tourism city but also an effective and efficient platform between China and Latin America.

The consolidation of its inherent characteristics such as the long-established historical links with the Latin world, the unique cross-cultural experience, the status of Special Administrative Region of China and the regional development initiatives such as the Pearl River Delta \& Pan-Pearl River Delta development initiatives and the Greater Bay Area initiative is, in effect, leveraging Macau's soft-power attributes to its advantage. By serving as an effective soft-power hub 
of the nation, Macau can contribute more in helping build an extension of the "Belt and Road" to Latin America, specifically in the Pacific Rim.

Furthermore, as a special administrative region embracing freedom in different aspects, Macau is having a comparative advantage over the other mainland cities. By making good use of the formal instruments like sister-cities agreement, trade office, trade agreements or other international agreements and the informal mechanisms such as the non-governmental events and activities organized by the NGOs, Macau can assist further in enhancing the relations or facilitating the establishment of official ties between China and the Latin American countries in a more pragmatic and flexible way.

\section{Literature}

- Candice Goucher and Linda Walton (2008): "WORLD HISTORY, JOURNEYS: Journeys from Past to Present".

- Cathryn H. Clayton (2009): “Sovereignty at the Edge: Macau \& the Question of Chineseness", Harvard University Asia Center.

- Constitutional and Mainland Affairs Bureau, Hong Kong SAR Government (2017) "Framework Agreement on Deepening Guangdong-Hong KongMacao Cooperation in the Development of the Bay Area" http://www.cmab. gov.hk/doc/issues/bay_area/Framework_Agreement_e.pdf

- Department of Latin American and Caribbean Affairs, Ministry of Foreign Affairs of China (April, 2016) "Basic Information about China-CELAC Forum”. http://202.171.253.67/www.chinacelacforum.org/eng/ltjj_1/ P020161207421177845816.pdf

- Hao, Zhidong (2011): Macau History and Society, Hong Kong University Press in joint publication with the University of Macau.

- Hong Kong Trade Development Council (2 Dec 2016) "PRD Economic Profile", http://china-trade-research.hktdc.com/business-news/article/Factsand-Figures/PRD-Economic-Profile/ff/en/1/1X000000/1X06BW84.htm

- Statistics and Census Service of Macau SAR government (2016) "INTERCENSOS 2016 RESULTADOS GLOBAIS" http://www.dsec.gov.mo/ Statistic.aspx?NodeGuid=ee77eb29-fd1b-4f13-8a2d-3181e93adb05

- The Gaming Inspection and Coordination Bureau of Macau SAR government (2017): "Monthly Gross Revenue from Games of Fortune in 2017 and 2016", http://www.dicj.gov.mo/web/en/information/DadosEstat_mensal/2017/ index.html

- University of Macau (26 May, 1998): "Basic Law of the Macao Special Administrative Region of the People' s Republic of China”. http://www. umac.mo/basiclaw/english/main.html 


\section{MAKAO KAO SPONA IZMEĐU KINE I LATINSKE AMERIKE}

Od početka 21. veka svedoci smo održivog i ubrzanog razvoja odnosa izmedu Kine $i$ Latinske Amerike i Kariba. Postoji široko ubeđenje da se u budućnosti može predvideti jača veza između ovih regiona koja obećava.

Istorijski posmatrano, Makao je portugalska trgovačka postaja na dalekom istoku već više od 442 godine. Posle primopredaje 1999. godine, Makao je zvanično vraćen Kini kao poseban administrativni region. Danas Makao predstavlja „najveći svetski kockarski kapital” i deo područja Velkog zaliva od nacionalnog strateškog značaja u južnoj Kini. Koristeći svoje osnovne prednosti i posebne privilegije, Makao može ići mnogo dalje, ne samo kao grad igara $i$ turizma, već i kao efikasna i efektivna platform između Kine $i$ Latinske Amerike.

Osim toga, uz novu megastrukturu, ogromnu logističku mrežu i inicijativu Oblasti šireg zaliva, Makao može da posluži kao efikasna baza nacije za pomoć u izgradnji produžetka "Pojasa i puta" prema Latinskoj Americi i regionu Pacifika.

Ključne reči: Makao, poseban administrativni region Kine, Oblast šireg zaliva, Pojas i put, odnosi Kine i Latinske Amerike 